\title{
DEVELOPING ENGLISH FOR TOURISM MATERIALS TROUGH STAKEHOLDERS' NEEDS ANALYSIS
}

\author{
Indah Puspitasari \\ English Diploma Program, Faculty of Humanities, Jenderal Soedirman University, Indonesia \\ E-mail: indahpuspitasari876@gmail.com
}

APA Citation: Puspitasari, I. (2018). Developing English for tourism materials trough stakeholders' needs analysis. English Review: Journal of English Education, 7(1), 147-156. doi: 10.25134/erjee.v7i1.1534.

Received: 19-08-2018

Accepted: 27-10-2018

Published: 01-12-2018

\begin{abstract}
Banyumas currently grows well in various aspects especially in tourism. Tourism plays an important role in this regency because it becomes one of the mainstays of Banyumas revenue sector. A phenomenon occurs today is the number of hotels in Banyumas arises every year. It is very important to prepare human resources; especially those who have good skills in tourism and English. This paper aims at explaining the stakeholders' overview of skills needed, topic needed, and difficulties encountered. The stakeholders here are tour agencies, hotels, and Youth, Sports, Culture and Tourism Office of Banyumas Regency. This is a qualitative research method which has several research steps. First, library study is a method of collecting data and it is also used to compile research instruments. The second step is to share the questionnaires to the sampling and the last is analysing the results. The results of this study showed that; 1) the required skills are speaking $(100 \%)$, listening $(75 \%)$, writing $(25 \%)$, and reading $(25 \%), 2) 80 \%$ of the topics offered in the questionnaire are required by all stakeholders. The topics are about hotels and tourism materials, and 3) difficulties encountered in active cooperating with tourism industry, less practice in explaining tourism city map, and listening different accents such as English speakers from China, Japan, and India. In conclusion, these findings regarding the skills and topics needed can be used to develop English for Tourism materials.
\end{abstract}

Keywords: English for tourism; English for specific purposes; needs analysis; developing materials; tourism; Banyumas.

\section{INTRODUCTION}

A current phenomenon is the shift of public consumption for retail shopping. Now, people choose to save their money in banks and use it for vacationing in tourist attractions. As mentioned by Kompas Daily on November 6, 2017 that there is a shift in consumer behavior patterns from shopping to tourism which is marked by several indicators of household consumption growth in the third quarter of 2017. One of the indicators in question is an increase in public consumption in hotels and restaurants. In the third quarter of 2017, restaurants and hotels grew significantly from 5.01 percent in the third quarter of 2016 to 5.52 percent in the third quarter of 2017. Indicators for restaurants, hotels, and recreation continue to increase, although the contribution to household consumption has not seen a significant about just 14 percent to 15 percent.

The opinion reinforces data from the Ministry of Tourism and Creative Economy of tourism growth in Indonesia which tends to increase every year. Data in 2015 showed 911.704 foreign tourists coming to Indonesia and experiencing an increase in 2016 and 2017 which reached 1.404.664. The growth of tourism and hospitality is also felt in Banyumas regency. The number of hotels in Banyumas Regency which was 182 in 2014 currently reaches 232 hotels in 2017.

From the data above, it is very important for Banyumas Regency to prepare qualified human resources from the tourism sector and one way is through stakeholders' needs analysis. Stakeholders are individuals or groups that can influence and or be 
influenced by a particular achievement. Stakeholders have three categories:

1) Main stakeholder: stakeholders who have a direct interest in a policy of the community.

2) Stakeholder supporters: do not have a direct link to a policy but have a concern, for example: NGOs, Universities, institutions.

3) Key stakeholder: having legally authorized in decision making, such as government, parliament, office, etc.

On the other hand, stakeholders of tourism include tourists, businessmen, governments, communities, universities, communities, and non-governmental organizations (Pitana, 2009). Thus, the stakeholders referred to by the authors in this study are the main stakeholder of the hotel owner and tour agent and key stakeholders, namely the Department of Youth, Sports, Culture and Tourism of Banyumas Regency as policy makers. The institution here is a stakeholder's supporter who concern to the main and key stakeholders' needs.

Universities as one of tourism stakeholder have an important role related to research implementation. The results of lecturers' research, such as, needs analysis, market analysis, consumer survey and others can be used by tourism industry to develop the tourism resources they have. According to Pitana (2009), tourism resources are resources related to tourism development which include: natural resources, human resources, cultural resources, and special request resource. Here, the authors choose to develop human resources tourism because every element of tourism requires human resources to move it.

Moreover, needs analysis is part of curriculum development or known as Curriculum and Material Development. The material development process is a central element in language teaching programs. The development system can be conceptualized into three interrelated processes. First, the planning process includes analyzing the needs of learners, institutional expectations and resource availability, and defining learning objectives and translating needs and objectives into materials and learning activities. Second, the learning process (enacting process) includes using teaching materials and conducting teaching and learning activities in the classroom. Third, the evaluation process is an assessment the progress of learners toward the achievement of goals.

That process is a system of development that should be done by each college. The focus of this research is on the first stage of development that is the planning process which includes the needs analysis. Needs analysis is a procedure for gathering information about the learners' needs. The same opinion is also expressed by Richards (2001) that the procedure used to collect information about the learners' needs is known by the term needs analysis.

The main purpose of the needs analysis activity is to prepare a set of learning objectives and material selection. The triangulation approach can be used in performing needs analysis because one source of information may be incomplete or partial. Different stakeholders have different perspectives on needs and solutions. Needs analysis usually involves the gathering of information from more than one referent group. According to Richards (2001, p. 60), information can be obtained from finding relevant theories such as books, journal articles, reports and research results, and collecting information from multiple respondents.

There are several studies on the needs analysis of English for Specific Purposes, i.e. Trang (2015), Amali (2015), and Darrel (2018). In his study, Trang (2015) found that the most important need among English language skill of tourism employees is speaking then followed by listening, writing and reading. Although the needs analysis of English for Specific Purposes has been widely done, as far as the author's observation, Banyumas tourism stakeholders' needs analysis has never been done. Therefore, this study tries to explain 
ENGLISH REVIEW: Journal of English Education Volume 7, Issue 1, December 2018

the stakeholders' overview of skills needed, topic needed, and difficulties encountered.

\section{METHOD}

The study was a qualitative case study. According to Merriam in Cohen (2005, p. $185)$, there are three types of case studies, namely descriptive, interpretative, and evaluative. The writer used descriptive method to describe the skill needed, topic needed and difficulties encountered.

The participants were the tourism stakeholders of Banyumas regency including the Youth, Sports, Culture and Tourism Office of Banyumas Regency, hotels and tour agency. The sampling technique was purposive random sampling. Based on data from Banyumas Hotel and Restaurant Association (PHRI) and Youth, Sports, Culture and Tourism Office of Banyumas Regency, the number of hotels in Banyumas in 2017 is 232 . There are only 12 star hotels and only three hotels have been certified by the Business Certification Institute (LSU). The author took a sample of $20 \%$ of the star hotels population. The samples taken were four star hotels in Banyumas. Meanwhile, the total number of Banyumas Tour Agency, according to the Association of tourism Banyumas (Asita), was 31 agencies. The author took $20 \%$ as sample (six tour agencies).

This study applied two methods of collecting data; questionnaire and library study. Questionnaires are instruments used to obtain information from respondents, while the library study was used to collect relevant theories to make research instruments in the form of questionnaires and used to analyze the needs. The method of data analysis in this qualitative study is descriptive method. There are more research data found in the field and will be analyzed and supported by the theories that are available and relevant (Sugiyono, 2009, p. 13-14). Descriptive analysis is used to describe and analyze the needs of stakeholders of English for Tourism. Then, writer used the results to develop English for Tourism teaching materials. For data
p-ISSN 2301-7554, e-ISSN 2541-3643

https://journal.uniku.ac.id/index.php/ERJEE

validation, the authors uses triangulation. The triangulation approach can be used in performing needs analysis because one source of information may be incomplete or partial.

\section{RESULTS AND DISCUSSION}

In this section, the authors explain the curriculum of higher education. This analysis is used to find out the purpose of the education system and to make decisions in syllabus and material design. According to Minister of Education and Culture, law No.232/U/2000 defines the curriculum as; "a set of plans and arrangements concerning the content and study materials and lessons as well as the way of delivery and assessment used as guidelines for the conduct of business or teaching-learning activities in Higher Education." The curriculum is a program developed and implemented to achieve educational goals. The curriculum can be viewed as a plan to build a house. The orientation is for the future. Thus, curriculum objectives play a major role in achieving program objectives. As we know that currently, there are changes in curriculum conducted by the Ministry of Education and Culture of Indonesia. Competency-Based Curriculum changes to KKNI (Indonesia National Qualification Framework). On the curriculum of KKNI the competence is expected to be able to pair, equalize and integrate (from junior high school to postgraduate level) between the field of education, the field of job training and work experience in the framework of giving the recognition of work competence in accordance with the structure of work in various sectors (Ministry of Education and Culture, 2011).

The curriculum is directed to equalize graduate qualifications so as to compete in the world of work. Sourced from the Ministry of Education and Culture (2011), description of the competencies achieved for the Diploma level means that language teaching at the diploma level focuses on the achievement of learning by students. They 


\section{Indah Puspitasari}

Developing English for tourism materials trough stakeholders' needs analysis

must be able to compete in the world of work.

Based on the above description, the author draws the following conclusions: 1) The type of curriculum used as a reference needs analysis is referring to the Indonesian National Framework Curriculum. This means that language teaching at the diploma level focuses on the achievement of learning that must be mastered by students to be able to compete in the world of work, and 2) The purpose of teaching English in Higher Education is focused on improving quality and competitive outcomes at local, regional and international levels. The Indonesian National Framework Curriculum is a systemic framework. This means that all competencies should be built. It includes major competencies (understanding the four basic English skills of listening, speaking, reading and writing) as well as supporting competencies such as linguistic competence and communication strategies.

\section{Developing English for tourism materials}

Curriculum development processes are central elements in language program. According to Snow and Kamhi-Stein (2006, p. v-vi), the system in a curriculum can be conceptualized as three interrelated process: 1) Planning processes which include analyzing the needs of learners, the expectation of the institution and the availability of resources, deciding on the learning aims and goals needed to achieve them and organizing them in a principle way, and translating the aims into materials and activities; 2) Enacting (teaching and learning) processes which include using the materials and doing the activities in the classroom, and adjusting them according to learners' needs, abilities and interests; and 3) Evaluation processes which include assessing learners' progress toward and achievement of the aims, adjusting the aims in response to learners' abilities and needs, and gathering information about the effectiveness of the aims, organization, materials, and activities.

This research refers to planning processes which focuses on needs analysis. This is very important because it is the basic research to continue to the next steps, such as enacting process which includes materials design, teaching and learning process at the classrooms.

English for Specific Purposes (ESP) is a language teaching approach where content and methods are based on students' reasons for learning. So, ESP's focus is to make English classes more relevant to the needs of students. ESP is a specific learning. English for Tourism is a teaching approach in order to achieve the goal or competence of students to mastery of English for professional purposes. Here is the position of English for Tourism as a branch of ESP.

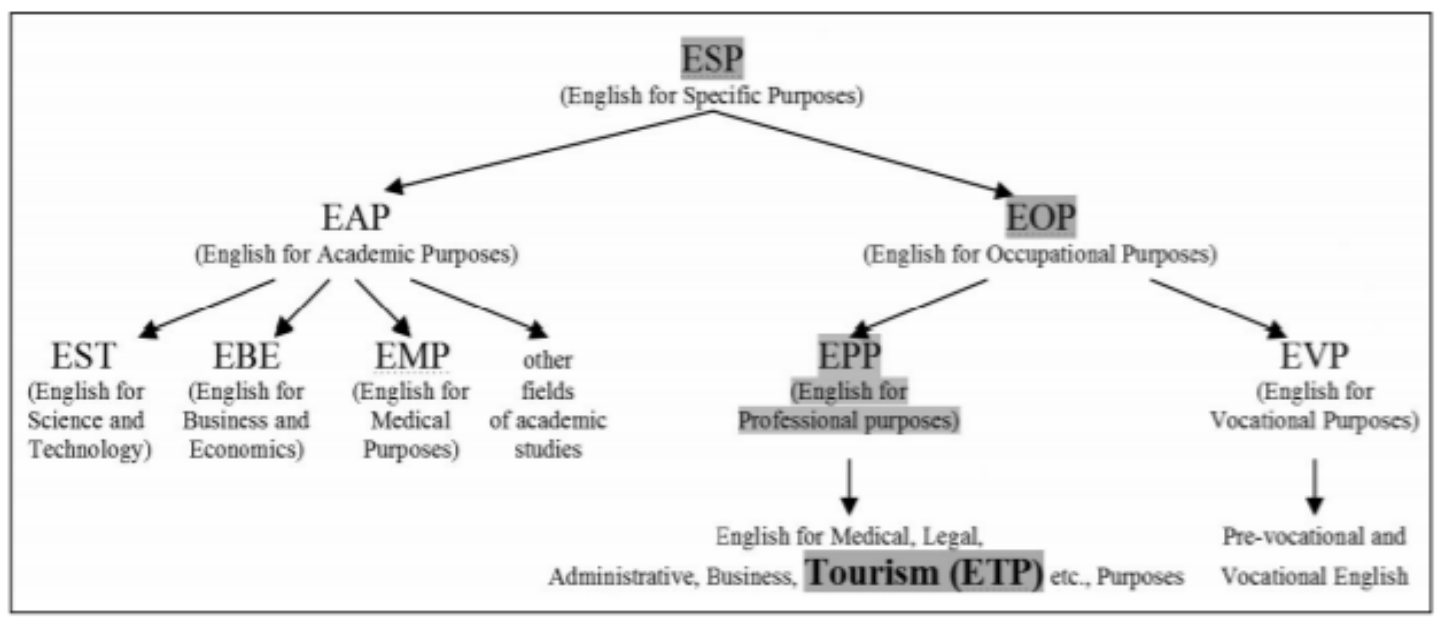

Figure 1. The position of English for tourism 
ENGLISH REVIEW: Journal of English Education Volume 7, Issue 1, December 2018

Pitana (2009) explains a tourism area facility has conditions in terms of development; something to see, something to do (activities that make tourists stay longer), something to buy (shopping area), how to arrive (transportation accessibility), and how to stay (hotel).

Selection of English for Tourism material refers to the above, because stakeholders will see those indicators as a benchmark of their success. In the questionnaire of needs analysis, the authors include the following elements:

1) Skill needed (listening, speaking, reading, writing)

a) Listening - It is essential for oral interaction as the students would find themselves talking with professional contacts about computers or in conferences and workshops about computers. The writer takes computer-related topics with exercises to listen for general and specific information, exercises to fill in the gaps with technical vocabulary and note taking.

b) Speaking - It is a necessary skill where the students must focus on the language specific to the fields of knowledge and not on general English. So, the related items such as topics, grammar and vocabularies still must be in line with the field. The students have to practice of grammar points in the specific topics needed.

c) Reading - It is a necessary skill where the students must focus on reading process, such as scanning, skimming, guessing words from context and making inferences in the specific discourse

d) Writing - It is a necessary skill in a context where most jobs in computing are in international companies whose written communication is in English. The materials are computer-related topic. It also focuses on verb agreement, connectors of time, sequencing,
p-ISSN 2301-7554, e-ISSN 2541-3643 https://journal.uniku.ac.id/index.php/ERJEE

structure and organization ideas, such as describing process, describing functions, writing advantages and disadvantages, reporting problems, writing a curriculum vitae, and writing a summary (Snow \& KamhiStein, 2006, p. 47-50).

2) Topic needed

a) Something to see - The expected ability is about tour guiding, presenting destination skill, and explaining weather condition.

b) Something to do (activities that make tourists stay longer) - The expected ability is about describing tourism objects.

c) Something to buy (shopping area) The expected ability is about dealing with Money and number

d) How to arrive (transportation accessibility) - The expected ability is about dealing with transportation and tourist information officers.

e) How to stay (hotel) - The expected ability is about explaining types of accommodation, hotel facilities, staffing and internal organization, reservation, check in and checkout, hotel and restaurant services, complaints and solution.

3) Difficulties encountered

\section{Stakeholders' needs analysis}

Stakeholder needs analysis is equally important with student needs analysis. As Pitana (2009) notes stakeholder tourism is a tourist, businessman, government, community, college, community and nongovernment organization. The stakeholders consist of the main stakeholders (hotels and tour agencies) and the key stakeholders (the Office of Youth, Sports, Culture and Tourism Banyumas regency as a policy maker). Stakeholder needs analysis results are as follows.

\section{Hotels needs analysis}

Four hotels that filled the questionnaire chose speaking and listening as their skill needed. As it can be seen in Table 1, speaking is the most required skill in hotel 


\section{Indah Puspitasari}

Developing English for tourism materials trough stakeholders' needs analysis

industry. This is in accordance with the competence of human resources (HR) that they hope, excellence human resources in spoken communication. Moreover, Table 2 shows the result of stakeholders' topic needed. The stakeholders chose these topics as their learning materials to improve their English competence.

Table 1. Percentage of hotels' skill needed

\begin{tabular}{lc}
\hline \multicolumn{1}{c}{ Skills } & Percentage \\
\hline Speaking & $100 \%$ \\
Listening & $75 \%$ \\
Reading & $25 \%$ \\
Writing & $25 \%$ \\
\hline
\end{tabular}

Table 2. Percentage of hotels' topic needed to improve their English

\begin{tabular}{|c|c|c|}
\hline Topics & Yes & $\%$ \\
\hline Greeting, facial expression and body movement & 3 & 75 \\
\hline Types of accommodation & 3 & 75 \\
\hline Hotel facilities & 2 & 50 \\
\hline Staffing and internal organization & 3 & 75 \\
\hline 5. Reservation and check -in & 4 & 100 \\
\hline Hotel and restaurant services & 4 & 100 \\
\hline Phone calls & 4 & 100 \\
\hline 8. Money and number & 1 & 25 \\
\hline 9. Complaints and solution & 3 & 75 \\
\hline 10. Describing tourism object & 3 & 75 \\
\hline 11. Tour guiding & 3 & 75 \\
\hline 12. Presentation skill (presenting destination ) & 3 & 75 \\
\hline 13. Itinerary and schedule & 1 & 25 \\
\hline 14. Weather & 1 & 25 \\
\hline $\begin{array}{l}\text { 15. Transportation (understanding information about } \\
\text { public transportation) }\end{array}$ & 3 & 75 \\
\hline 16. Dealing with tourist information officers & 3 & 75 \\
\hline
\end{tabular}

As it can be seen in Table 2, there are some topics required by stakeholders. The writer selected some topics which have $50 \%$ or more needed. They hope that they are able to master the following topics:

Greeting, facial expression and body movement (non verbal communication)

Types of accommodation

Hotel facilities

Staffing and internal organization

Reservation and check -in

Hotel and restaurant services

Phone calls

Complaints and solution

Describing tourism object

Tour guiding

Presentation skill (presenting destination)

Transportation (understanding information about public transportation and direction)

Dealing with tourist information officers
In the final column, the author designs a questionnaire regarding the difficulties encountered. Some of the difficulties are less practice of English for hotels and tourism, inactive cooperating with tourism industry to strengthen communication and business network from all tourism stakeholders, less practice in reading or explaining tourism city map and less practice in using and listening English materials with different accents such as English speakers from China, Japan, India that are sometimes difficult to understand by stakeholders. The Human Resources Head of Hotels said that many guests who stay in their hotels are people from those countries. Some of them asked about tourism objects in Banyumas. They wanted to visit and ask the direction to be there. The staffs are not fluent enough in speaking English especially in asking and giving directions. 
ENGLISH REVIEW: Journal of English Education Volume 7, Issue 1, December 2018

\section{Tour agencies needs' analysis}

Six tour agencies filling the questionnaire chose speaking and listening as the skill needed. As it can be seen in Table 3, speaking is the most required skill by tour agencies. They use their speaking
p-ISSN 2301-7554, e-ISSN 2541-3643

https://journal.uniku.ac.id/index.php/ERJEE competence to guide international tourist. Moreover, Table 4 shows the result of stakeholders' topic needed. The stakeholders chose these topics as their learning materials to improve their English competence.

\begin{tabular}{|c|c|c|}
\hline Skills & Yes & Percentage \\
\hline Speaking & 6 & $100 \%$ \\
\hline Listening & 4 & $70 \%$ \\
\hline Reading & 2 & $25 \%$ \\
\hline Writing & 2 & $25 \%$ \\
\hline
\end{tabular}

Table 4. Percentage of tour agencies' topic needed to improve their English

\begin{tabular}{lcc}
\hline \multicolumn{1}{c}{ Topics } & Yes & \% \\
\hline 1. Greeting, facial expression and body movement & 4 & 75 \\
2. Types of accommodation & 4 & 75 \\
3. Hotel facilities & 3 & 50 \\
4. Staffing and internal organization & 3 & 50 \\
5. Reservation and check -in & 6 & 100 \\
6. Hotel and restaurant services & 6 & 100 \\
7. Phone calls & 6 & 100 \\
8. Money and number & 1 & 25 \\
9. Complaints and solution & 3 & 50 \\
10. Describing tourism object & 3 & 50 \\
11. Tour guiding & 6 & 100 \\
12. Presentation skill (presenting destination ) & 3 & 50 \\
13. Itinerary and schedule & 3 & 50 \\
14. Weather & 1 & 25 \\
15. Transportation (understanding information about & 3 & 50 \\
public transportation) & & \\
16. Dealing with tourist information officers & 4 & 75 \\
\hline
\end{tabular}

As it can be seen in Table 4, there are some topics required by tour agencies. The writer selected some topics which have $50 \%$ or more needed. Tourism human resources are hopefully capable of mastering English in the following topics:

Greeting, facial expression and body movement (non verbal communication)

Cross cultural understanding

Types of accommodation

Hotel facilities

Staffing and internal organization

Reservation and check-in

Hotel and restaurant services

Phone calls

Complaints and solution

Describing tourism object

Tour guiding

Presentation skill (presenting destination)
Itinerary and schedule

Transportation (understanding

information about public transportation and direction)

Dealing with tourist information officers

In the final column, the author designs a questionnaire regarding the difficulties encountered. Some of the inputs are: most tour agencies in Banyumas only conduct domestic tours. Banyumas Tourism is still lack of promotion either in Bahasa Indonesia or English. It makes the foreign tourists rarely visit Banyumas. One effort of tour agencies in Banyumas is to build networking. They develop tourism networking in Indonesia or even with other countries. They also build the network by writing Indonesia tourism travel blog which is used to attract international tourists to 
come to Indonesia. They shared a problem of writing a good travel blog in English. They realize their weakness so that they invite the English teacher or lecturer to improve their English.

\section{Youth, sports, culture and tourism office of Banyumas Regency needs analysis}

The writer met Mr. D. Jatmiko, head of culture and Tourism Office, to discuss the tourism needs analysis. He said speaking and writing are very important skill for tourism because ability to speak and write is used as a means of communication, promotion and network expansion. Through this ability, they are able to promote tourism and activities that can attract and make tourists stay longer, buy something in shopping areas, use the local transportation and stay in hotels. Tourism human resources are hopefully capable of mastering English in the following topics:

Greeting, facial expression and body movement (non verbal communication)

Cross cultural understanding

Types of accommodation

Hotel facilities

Staffing and internal organization

Reservation and check -in

Hotel and restaurant services

Phone calls

Complaints and solution

Describing tourism object

Tour guiding

Presentation skill (presenting

destination)

Itinerary and schedule

Weather

Transportation (understanding information about public transportation and direction)

Dealing with tourist information officers

All the topics in the questionnaire are needed because according to D. Jatmiko, the mastery of the vocabulary of the tour guides in every tourist attraction in Banyumas is still very limited. In the final column, the author designs a questionnaire regarding the difficulties encountered. Some of the difficulties written in questionnaires and interviews are limitations of vocabulary, limitation of expanding business network through internet media and make overseas market as target, limitation of tourism industry players who use English as a promotional tool on the internet, and limitations in the ability to write travel blogs.

From the three stakeholders need analysis above, it can be concluded that; 1) the required skills are speaking (100\%), listening $(75 \%)$, writing $(25 \%)$, and reading $(25 \%)$. The writer draws a conclusion from the mean of hotels and tour agencies' needs analysis then the information from Head of Banyumas Culture and Tourism Office is used to make data validation trough triangulation; 2) Topic needed, all the topics offered in the questionnaire are required by all stakeholders except money, number, and weather; and 3) Difficulties encountered in the field are; less practice of English for hotels and tourism, inactive cooperating with tourism industry to strengthen business network from all tourism stakeholders, less practice in reading and explaining tourism city map, and less practice in using and listening English materials with different accents, such as English speakers from China, Japan, and India that are sometimes difficult to understand by stakeholders.

\section{CONCLUSION}

Improvements will always be made in the development of learning materials because teachers and lecturers are required to be sensitive to the development needs of students and society. Banyumas, one of the biggest regency in the south of Central Java Province, also develops in many sectors, especially in tourism industry. Number of hotels in Banyumas is growing and the consumption of society right now is changing from retail shopping into vacationing in tourist attractions. Those phenomena make Banyumas and university must be ready to prepare qualified human resources in Tourism sector. English diploma Program of Jenderal Soedirman 
ENGLISH REVIEW: Journal of English Education Volume 7, Issue 1, December 2018

University has Tourism concentration. It will help Banyumas to prepare human resources in this sector. To make in line with the government needs, hotel, tour agency and university, the author conducted this research. The findings related to the skill needed, topic needed, and difficulties encountered. The results of this study are; 1 ) The required skills are speaking (100\%), listening $(75 \%)$, writing $(25 \%)$, and reading $(25 \%) ; 2) 80 \%$ of the topics offered in the questionnaire are required by all stakeholders. The topics are about hotels and tourism materials; and 3) Difficulties encountered are; less practice of English for hotels and tourism, inactive cooperating with tourism industry to strengthen business network from all tourism stakeholders, less practice in reading and explaining tourism city map, and less practice in listening different accents such as English speakers from China, Japan, India that are sometimes difficult to understand by stakeholders.

\section{REFERENCES}

Amali, M. (2015). Relevancy of English tourism lesson plan with students' needs analysis at Vocational School 2 Padang. Padang: STKIP PGRI Sumatra Barat.

Cohen, L. (2005). Research methods in education. New York: Rutledge Taylor \& Francis Group.
p-ISSN 2301-7554, e-ISSN 2541-3643

https://journal.uniku.ac.id/index.php/ERJEE

Darrel, H. (2018). Analysis of students'feedback for a tourism English course based on group projects. Tokyo: Faculty of International Tourism, Toyo University. Retrieved October 19, 2018 from https://toyo.repo.nii.ac.jp/?action=pages_view_ main\&active_action=repository_view_main_ite m_detail\&item_id=10145\&item_no=1\&page_id $=13 \&$ block_id=17.

Kementrian Pendidikan dan Kebudayaan. (2008). Panduan umum pengembangan silabus. Jakarta: Kemendikbud RI.

Kementrian Pendidikan dan Kebudayaan Republik Indonesia. (2011). Kerangka kualifikasi nasional Indonesia. Retrieved October 1, 2018 from

http://www.dikti.go.id/files/atur/KKNI/Penyusu nan-LO-Prodi.pdf.

Pitana, D. (2009). Pengantar ilmu pariwisata. Yogyakarya: Penerbit Andi.

Richard, J. C. (2001). Curriculum development in language teaching. Cambridge: Cambridge University Press.

Snow \& Kamhi-Stein. (2006). Developing a new course for adult learners. New York: TESOL Inc.

Sugiyono. (2009). Metode penelitian pendidikan: Pendekatan kuantitatif, kualitatif dan $R \& D$. Bandung: Alfabeta.

Trang, B. T. T. (2015). Needs analysis of English language use in tourism: A case study of international travel companies in Vietnam. Unpublished master thesis. College of Language Arts, I-Shou University. 
Indah Puspitasari

Developing English for tourism materials trough stakeholders' needs analysis 